\title{
DRAINAGE-BASIN CHARACTERISTICS OF NORDAUSTLANDET ICE CAPS, SVALBARD
}

\author{
BY JULIAN A. DOWDESWELLL
}

(Scott Polar Research Institute. University of Cambridge. Cambridge CB2 IER. England)

ABSTRACT. Recent mapping of ice-surface and bedrock topography from airborne radio-echo sounding has shown that the ice caps of Nordaustlandet, Svalbard, are divided into a series of well-defined drainage basins. Three lines of evidence indicate that several distinctive modes of ice-flow regime characterize these basins: (1) comparison between observed and theoretical ice-surface profiles; (2) analysis of driving stresses; and (3) observations of ice-surface features on satellite imagery and air photographs. The drainage basins are inferred to behave in the following ways. First, basins with low driving stresses and surface profiles, some of them clearly stagnant, are associated with the quiescent phase between glacier surges. Secondly, the ice streams draining southern Vestfonna have low surface profiles, relatively low driving stresses, and marked shear zones at their margins. They are interpreted to be flowing continuously at a relatively faster rate than the ridges between them. Basal melting, perhaps combined with substrate deformation, is probably responsible for the regime of these glaciers. Thirdly, the remaining basins studied on Nordaustlandet have relatively high marginal driving stresses and high surface profiles. They are interpreted to be frozen to their beds, at least near their margins. Some of these basins may also surge, particularly those where a part of the basin is below sea-level, and therefore is probably underlain by considerable thicknesses of deformable sediments.

RÉsUMÉ. Caractéristiques des bassins d'écoulement des calottes glaciaires de la Nordaustlandet, Spitzberg. Des cartes récentes de la surface et du lit rocheux a partir de sondages radar aérien ont montré que les calottes glaciaires de la Nordaustlandet, sont divisées en séries de bassins d'écoulement bien definis. Trois critères indiquent que plusieurs types de régime d'écoulement caractérisent ces bassins: (1) comparaison entre profils superficiels observès et théoriques; (2) analyse de la cission au contact du lit; (3) observation des caractéristiques superficiels sur l'imagerie satellitaire et les photographies aériennes. Les différents bassins d'ècoulement sont supposés présenter les comportements suivants. Il y a tout d'abord des bassins, où la cission basale est faible et les profils longitudinaux de la surface abaissés, certains d'entre eux, nettement stagnant, sont associes aux phases quiescentes entre deux surges. En second lieu, les courants de glace drainant le Vestfonna méridional ont des profils de surface bas, des contraintes

\section{INTRODUCTION}

The ice caps of Nordaustlandet, Svalbard (Fig. 1), represent one of the largest glacierized areas outside the ice sheets of Antarctica and Greenland. Austfonna $\left(8105 \mathrm{~km}^{2}\right)$, Vestfonna $\left(2510 \mathrm{~km}^{2}\right)$, and Vegafonna $\left(295 \mathrm{~km}^{2}\right)$ are the three main ice masses (Dowdeswell and Drewry, 1985; Drewry and Liestøl, 1985). Recent mapping of ice-surface and bedrock topography from airborne radio-echo sounding and altimetric data shows that Austfonna and Vestfonna are divided into a series of well-defined drainage basins (Fig. 1a), and Austfonna in particular is also relatively unconstrained by bedrock topography (Dowdeswell and others, 1986). relativement basses et des zones de cisaillement marqué sur les bords. Ces courants sont supposes couler continuellement a une vitesse plus grande que leurs limites. La fonte basale, peut être combinée avec la déformation du substratum, est probablement responsable du régime de ces glaciers. Troisièmement les autres bassins étudiés sur le Nordaustlandet montrent de relativement fortes contraintes marginales et des profils de surface élevés. Ils sont interprétés comme étant gelés contre leurs lits, du moins près des bords. Certains de ces courants peuvent aussi "surger", spécialement ceux dont une partie se trouve en dessous du niveau de la mer, et qui reposent sur des épaisseurs considérables de sẻdiments déformables.

ZUSAMMENFAssung. Charakteristiken der Abflussbecken von Eiskappen auf Nordaustlandet. Spitzbergen. Die neuerliche Kartierung der Eisoberfläche und des Felsuntergrundes aus Echolotungen mit Flugradar hat gezeigt, dass die Eiskappen von Nordaustlandet in Spitzbergen in eine Reihe wohlabgegrenzter Abflussbecken unterteilt sind. Drei Beweisverfahren deuten darauf hin, dass einige unterschiedliche Arten des Fliessverhaltens des Eises diese Becken charakterisieren: (1) Vergleich zwischen beobachteten und theoretischen Profilen der Eisoberflăche; (2) Analyse der Treibdrucke; (3) Beobachtungen von Erscheinungen an der Eisoberflăche in Satelliten- und Luftbildern. Über das Verfhalten der Abflussbecken lasst sich folgendes aussagen: 1. Becken mit niedrigen Treibdrucken und Oberflăchenprofilen, einige davon sichtlich stagnierend, sind mit der Ruhephase zwischen Gletscherausbrüchen verknüpft. 2. Die aus Sũd-Vestfonna abfliessenden Eisstrơme haben niedrige Oberflăchenprofile, relativ hohe Treibdrucke und markante Scherzonen an ihren Răndern; sie werden als kontinuierliche Strome mit einer relativ hoheren Geschwindigkeit als die der dazwischenliegenden Rücken interpretiert. Schmelzen am Untergrund, vielleicht verbunden mit Deformation des Substrats, ist vermutlich für das Verhalten dieser Gletscher verantwortlich. 3. Die ubrigen, auf Nordaustlandet untersuchten Becken weisen relativ hohe randliche Treibdrucke und hohe Oberflăchenprofile auf. Es wird angenommen, dass sie am Untergrund festgefroren sind, zumindest in Randnăhe. Einige dieser Becken mogen auch ausbrechen, namentlich solche, wo ein Teil des Beckens unter dem Meeresspiegel liegt und deshalb vermutlich von deformierbaren Sedimenten erheblicher Măchtigkeit unterlagert wird.

This paper examines a number of these basins and suggests that three distinctive modes of ice-flow regime characterize different basins within the ice caps. These variable characteristics, which include surging outlet glaciers and ice streams, make Nordaustlandet ice caps an attractive area for long-term field and modelling studies as an analogue for the much larger Antarctic and Greenland ice sheets. Several lines of evidence are used to infer drainage-basin dynamics: (1) a comparison between observed and theoretical ice-surface profiles; (2) an analysis of the spatial pattern of driving stresses over the ice caps and along individual basin flow lines; and (3) observations of ice-surface features (e.g. shear zones) recorded on satellite imagery and air photographs. 


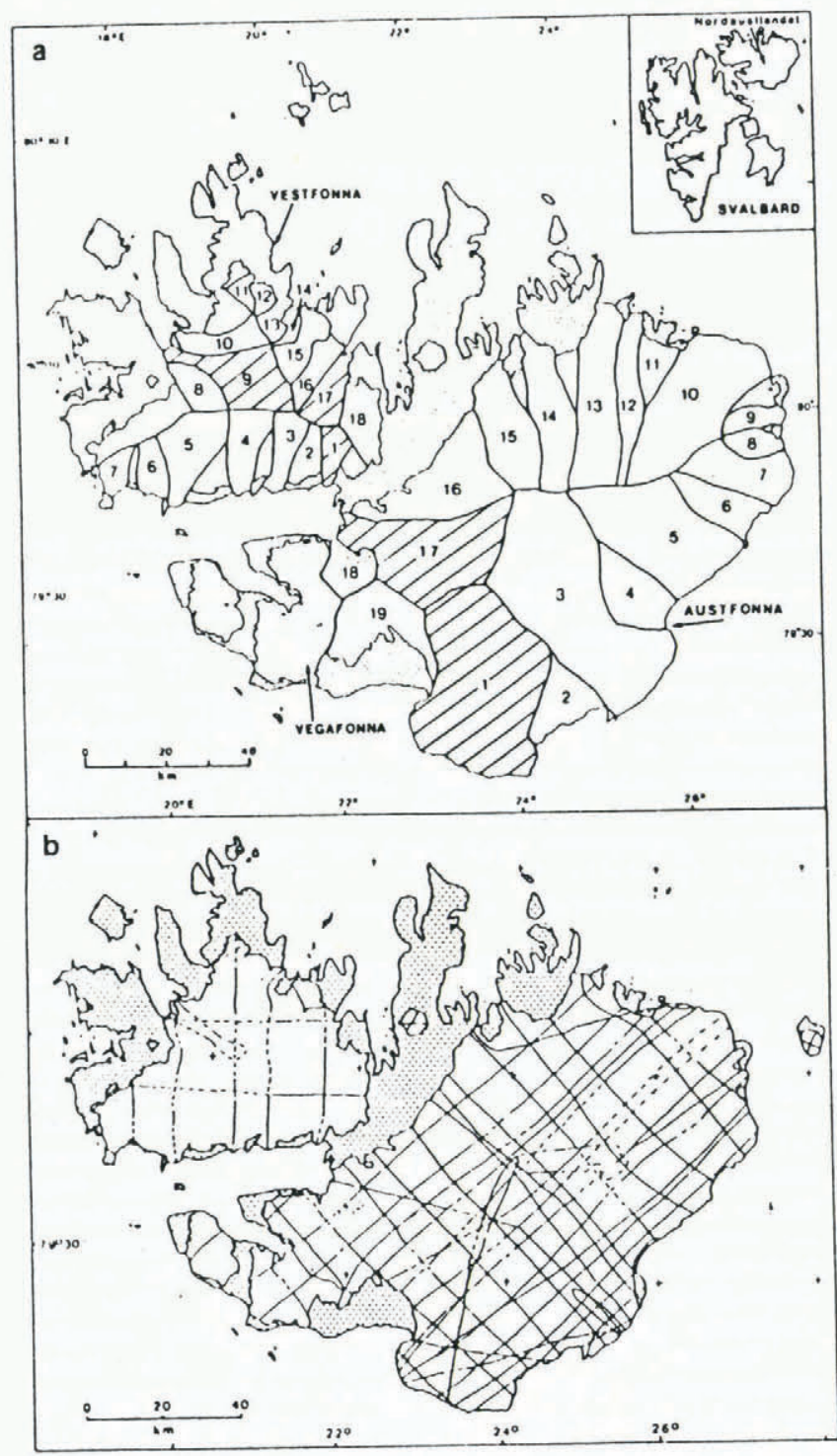

Fig. 1. (a), Map of the major ice-cap drainage basins on Nordaustlandet (from Dowdeswell and Drewry, 1985), with the location of Nordaustlandet within Svalbard inset. Basins observed to surge are shaded and stippled areas are bare land. The numbers are used to identify basins in the text and subsequent figures, where the prefix $A$ indicates an Austfonna basin and $V$ a Vestfonna basin.

(b) Aircraft flight lines over Nordaustlandet. Dashed lines indicate where radio-echo sounding bed returns were not received (Dowdeswell and others, 1986).

\section{METHODS}

Ice-cap long profiles are taken from aircraft pressure altimetric and terrain-clearance measurements collected during joint Scott Polar Research Institute and Norsk Polarinstitutt airborne geophysical investigations in Nordaustlandet during 1983 (Drewry and Liestol, 1985; Dowdeswell, unpublished). Only flight lines coincident $\left( \pm 10^{\circ}\right)$ with ice-cap flow lines, as defined from ice-surface elevation maps (Dowdeswell and others, 1986), are compared with theoretical profiles. Two-dimensional profiles along flow lines, with no significant convergence or divergence, are required because theory assumes that flow is in the longitudinal direction (Drewry, 1983[a]). In addition, bedrock elevations from $60 \mathrm{MHz}$ radio-echo sounding show how far the measured long profiles deviate from the flat, horizontal bed assumed by theory.

Aircraft altimetric and $60 \mathrm{MHz}$ radio-echo sounding data are also used to provide ice-surface slopes and thickness information for the calculation of basal shear or driving stresses. The $3400 \mathrm{~km}$ long network of aircraft flight lines over Nordaustlandet is shown in Figure $1 \mathrm{~b}$ to indicate the extent of interpolation necessary in the construction of a driving-stress map. The term "driving stress" is preferred to basal shear stress here to show that we are calculating the mean stresses that are in balance with basal shear stresses and longitudinal stress gradients (Cooper and others, 1982).

For mapping purposes, the ice caps were divided into overlapping boxes with $10 \mathrm{~km}$ long sides (a distance of approximately 20 times ice thickness) with $5 \mathrm{~km}$ displacement between their centres (Cooper and others, 1982). Surface-elevation data within each box were analysed using linear regression methods to define a plane, whose maximum slope and orientation was calculated. From this information, driving stresses $(\tau)$ in each box were obtained using the equation

$$
\tau=\rho_{\mathrm{j}} g h \sin \alpha
$$

where $\rho_{j}$ is mean ice density, $g$ is gravitational acceleration $h$ is ice thickness, and $\alpha$ is averaged ice-surface slope. Stresses over the ice caps were then contoured. The main source of error in this procedure comes from uncertainties in ice-surface elevation. Inaccuracies in surface elevation of +10 and $-10 \mathrm{~m}$ on either side of a box would yield an error of $\$ 4.5 \mathrm{kPa}$ for a $500 \mathrm{~m}$ thick ice mass. Altitudinal errors will generally be less than this (Dowdeswell and others, 1986), and errors in driving stress will therefore be $\pm 5 \mathrm{kPa}$ at worst. The calculation of driving stresses along drainage-basin flow lines also uses linear regression analysis to define surface slopes, but errors are less than for the driving-stress map because relative elevation is accurate to approximately $\pm 3 \mathrm{~m}$ along single flight lines. Surface elevations are smoothed over $3 \mathrm{~km}$ (approximately ten times ice thickness) in the driving-stress profiles, resulting in driving stresses that are somewhat higher and more variable than those mapped over the ice caps. This shorter smoothing length allowed the analysis of driving stresses over the greater part of several relatively short basin profiles. The change in smoothing distance does not compromise the analysis, because it is relative differences in driving-stress profiles between basins that are of principal interest here.

\section{ICE-CAP LONG PROFILES}

Observed ice-surface profiles from Nordaustlandet are compared with profiles from theory in order to study the behaviour of different drainage basins on the ice caps. Marked deviations of observed relative to theoretical profiles can, in conjunction with other data, be used to make inferences concerning the dynamics of these basins.

\section{Theoretical long profiles}

The general form of ice masses has been approximated by glaciological theory. Paterson $(1981,1983)$ suggested that in the absence of detailed mass-balance and temperature data, relatively simple theoretical calculations of ice-surface profiles should be preferred. Little accumulation and temperature data are available for Nordaustlandet ice caps, and the following calculations therefore make simple assumptions concerning ice rheology, basal conditions, and steady state. A simple theoretical profile, which has been used by Drewry (1983[a]) in a comparison between theoretical and measured surface profiles of the Antarctic ice sheet, is:

$$
h_{\mathrm{s}}=\left[\left(2 \sigma_{\mathrm{y}} / \rho_{\mathrm{i}} g\right)(L-x)\right]^{0.8}
$$

where $h_{s}$ is the elevation of the ice surface, $L$ is ice-mass half-width, $x$ is distance from the centre, and $\sigma_{y}$ is the yield stress of ice (see coordinate system in Figure 2). Ice is therefore approximated as a perfectly plastic material in Equation (2). A reasonable value for yield stress is $50 \mathrm{kPa}$ (Budd and Jenssen, 1975; Paterson, 1981) and, taking mean 

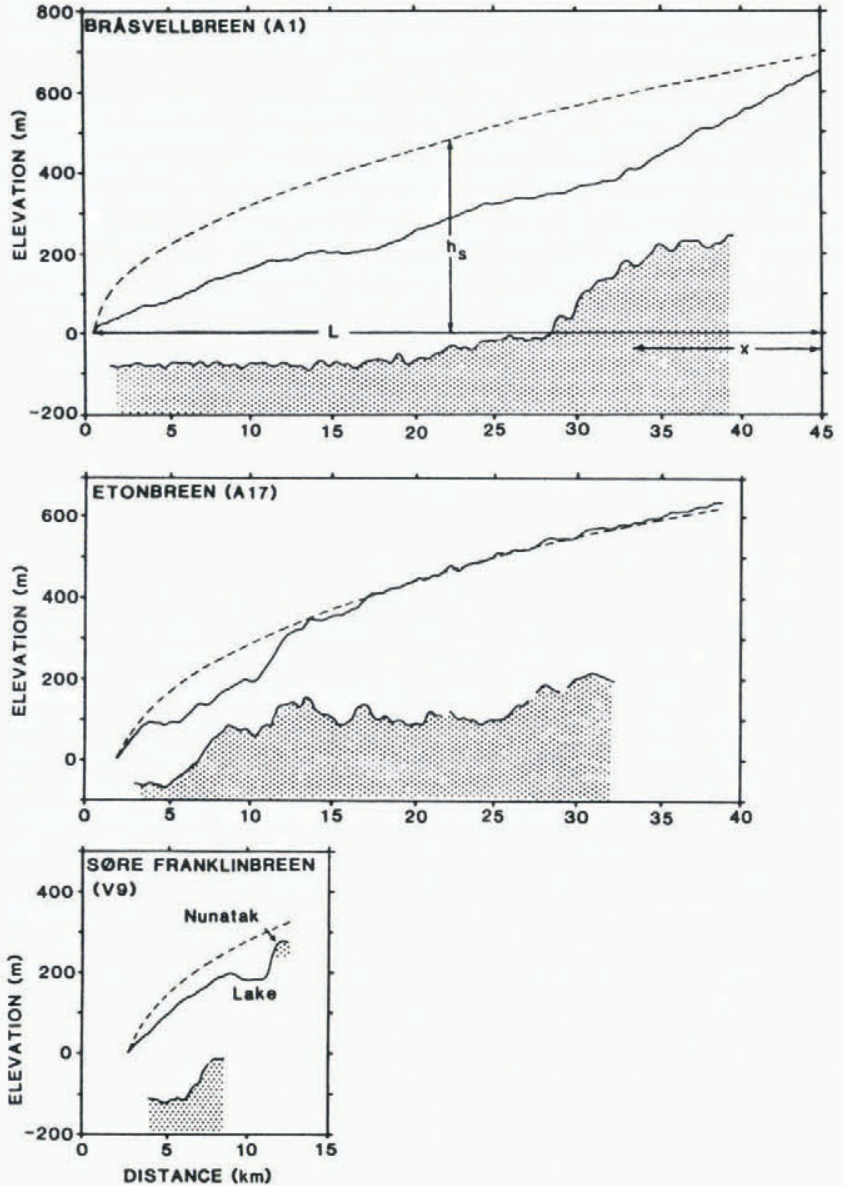

Fig. 2. Observed (solid line) and theoretical (dashed line) ice-surface profiles of three Nordaustlandet basins which have been observed to surge. The bed of each glacier, derived from radio-echo sounding, is included. Identification numbers locate the basins in Figure 1.

ice density as $910 \mathrm{~kg} \mathrm{~m}^{-3}$, substitution into Equation gives:

$$
h_{\mathrm{S}}=3.35(L-x)^{0.5} \text {. }
$$

The derivation of these equations rests on a number of assumptions (Paterson, 1981). The ice mass is assumed to lie on a flat, horizontal bed which is rigid. The presence of deformable sediments at the glacier bed will, however, lower the slope of the steady-state profiie (Boulton and Jones, 1979). Mass balance is also assumed to be uniform throughout the ice mass, which is in a steady state with flow more or less counter-balancing the effects of accumulation and ablation. Temperature, bed roughness, and other factors that may influence velocity are also assumed to be uniform over the ice mass. The base is assumed to be frozen and a change to melting at this interface would lower the surface slope considerably (Paterson, 1981).

\section{Ice-cap long profiles on Nordaustlandet}

Measured ice-surface profiles from Nordaustlandet are now compared with theoretical profiles calculated from Equation (3). A single theoretical profile is used throughout because it provides a standard against which measured profiles can be compared (e.g. Drewry and Robin, 1983). The method by which theoretical and observed surface profiles are fitted together is important in such a comparison. Theoretical curves are fitted consistently to present glacier termini in this study, following the procedure used by Drewry (1983[a], [b]). A small error is introduced to the comparison by short-term calving events which affect the location of the termini of some glaciers but are largely un- related to the longer-term glacier dynamics which influence the ice-surface profile. However, shifting the origin of theoretical profiles horizontally by $\pm 1 \mathrm{~km}$ (simulating a very large calving event in Nordaustlandet) makes no significant difference to the relationships between observed and theoretical curves discussed below.

Ice-surface profiles for the known surging glaciers Bråsvellbreen, Etonbreen, Søre Franklinbreen (Fig. 2), and Bodleybreen (Fig. 3) each fall below the theoretical profiles calculated from Equation (3) over all, or the lower part of,
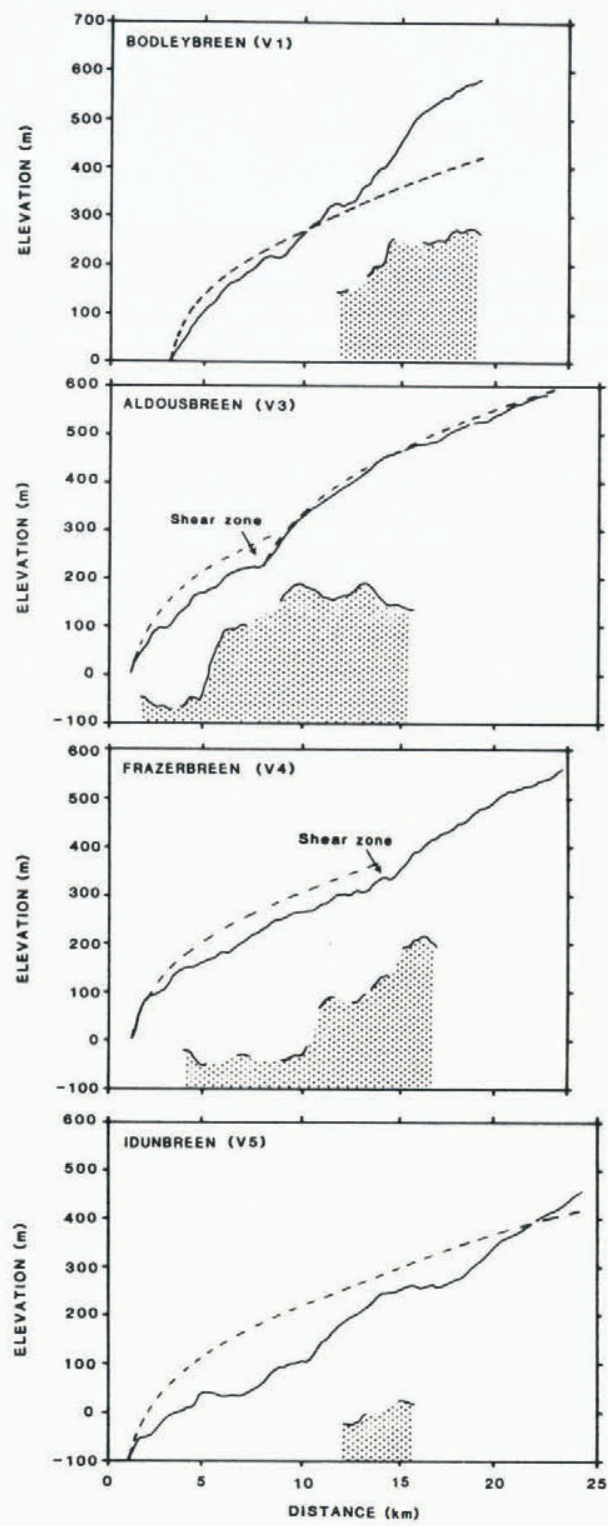

Fig. 3. Observed (solid line) and theoretical (dashed line) ice-surface profiles of the four principal outlet glaciers draining the south side of Vestfonna. The bed of each glacier, derived from radio-echo sounding, is also included. Identification numbers locate the basins in Figure 1.

their length. Surface-elevation data were not collected along flow lines on the other surging glaciers in Nordaustlandet (Fig. 1). The measured long profiles of the other three principal outlet glaciers draining south from the crest of Vestfonna also fall below the calculated profiles (Fig. 3). Steepening of observed surface profiles occurs in the marginal $1-2 \mathrm{~km}$ of Aldousbreen, Frazerbreen, and Idunbreen, where rock walls constrain these $3-5 \mathrm{~km}$ wide outlet glaciers. Drewry (1983[a], [b]) has pointed out a similar effect where ice masses such as Byrd and David Glaciers flow through the Transantarctic Mountains.

On both Aldousbreen and Frazerbreen, airborne 


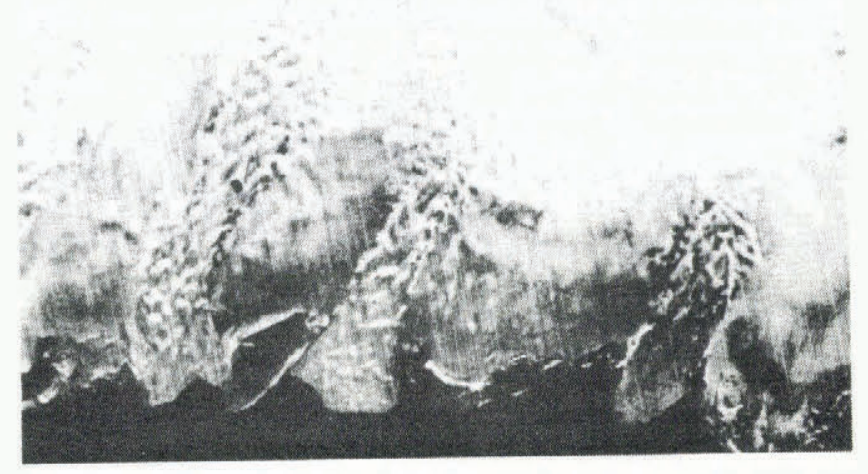

Fig. 4. The outlet glaciers of southern Vestfonna from band 7 of the Landsat 3 multi-spectral scanner. The scene (Id. No. 3016412314) was imaged on 16 August 1978 at a sun elevation of $22^{\circ}$.

traverses ran at an angle of about $10^{\circ}$ from ice-flow direction, and the breaks of surface slope at 8 and $14 \mathrm{~km}$, respectively, in Figure 3 represent passing from the outlet glaciers to the ice ridges separating them. The abrupt truncation at the lateral margins of each outlet glacier of crevassed ice that is rough at the kilometre scale is clearly shown on air photographs and Landsat imagery (Fig. 4), and has also been reported by parties traversing the area (Binney, [1925]; Sandford, 1929). These distinctive changes in ice-surface characteristics are interpreted as marking shear zones. Comparison between observed profiles and theoretical profiles with their origins at the glacier termini are not useful above this point, and a further curve has been superimposed on the measured profile of Aldousbreen with its origin at the shear zone (Fig. 3).

By contrast, most of the measured surface profiles from other drainage basins on Austfonna, Vestfonna, and Vegafonna occur above the theoretical profiles over much or all of their length (Fig. 5). Two exceptions to this general pattern are basin 3, on the south-east side of Austfonna, and Leighbreen (Fig. 5). Observed profiles in both these drainage basins fall generally below the calculated profiles, and that for basin 3 by a considerable margin. The interpretation of these marked differences in observed relative to theoretical ice-surface profiles is discussed below.

\section{DRIVING STRESSES IN NORDAUSTLANDET ICE CAPS}

On the scale of whole ice caps, the most obvious trend in driving stress on Nordaustlandet is the expected increase from low values close to ice divides to relatively high values near the margins (Fig. 6), a pattern similar to that found in both East and West Antarctica (Cooper and others, 1982). Minimum values of around $20 \mathrm{kPa}$ are present in the region of ice divides, but zero driving stresses are not mapped at the divides themselves due to the degree of averaging used in map production. Driving stresses reach approximately similar maximum values about $5 \mathrm{~km}$ from the margins of Austfonna and Vestfonna (Fig. 6).

The most obvious anomaly superimposed on the general increase in driving stress with distance from the ice divide is in the area of Brasvellbreen. Driving stresses reach only $15-30 \mathrm{kPa}$ in a zone extending up to $20 \mathrm{~km}$ from the glacier terminus, and increase to $40-50 \mathrm{kPa}$ farther up-glacier (Fig. 6). A further region of relatively low driving stress occurs near the margins of Austfonna in basin 3 , where stresses reach less than $40 \mathrm{kPa}$ (Fig. 6).

More detail concerning variations in driving stress both within and between drainage basins is given by the profiles
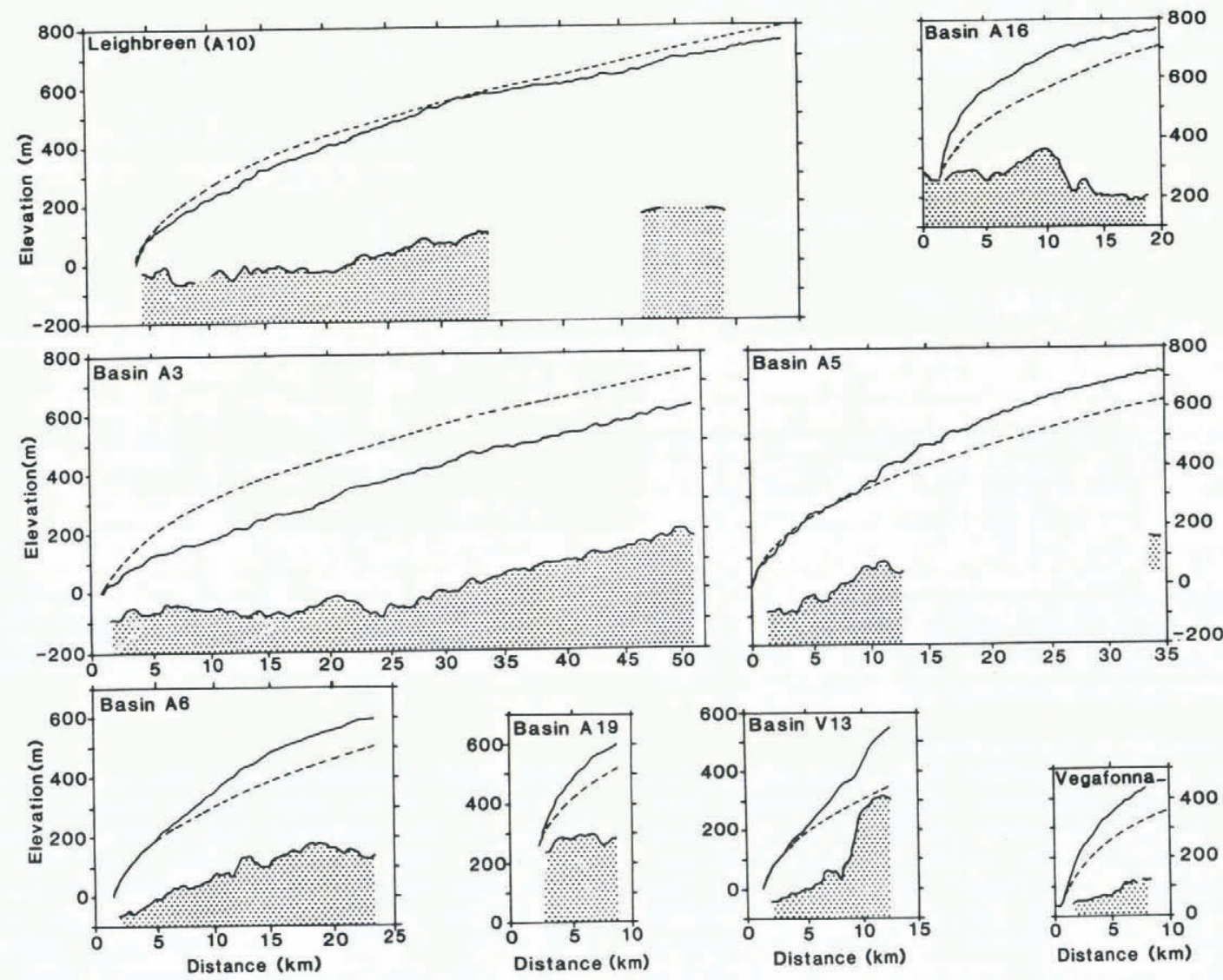

Fig. 5. Observed (solid line) and theoretical (dashed line) ice-surface profiles from eight drainage basins on Aust fonna, Vestfonna, and Vegafonna. The bed of each glacier, derived from radio-echo sounding, is included. Identification numbers locate the basins in Figure 1. 


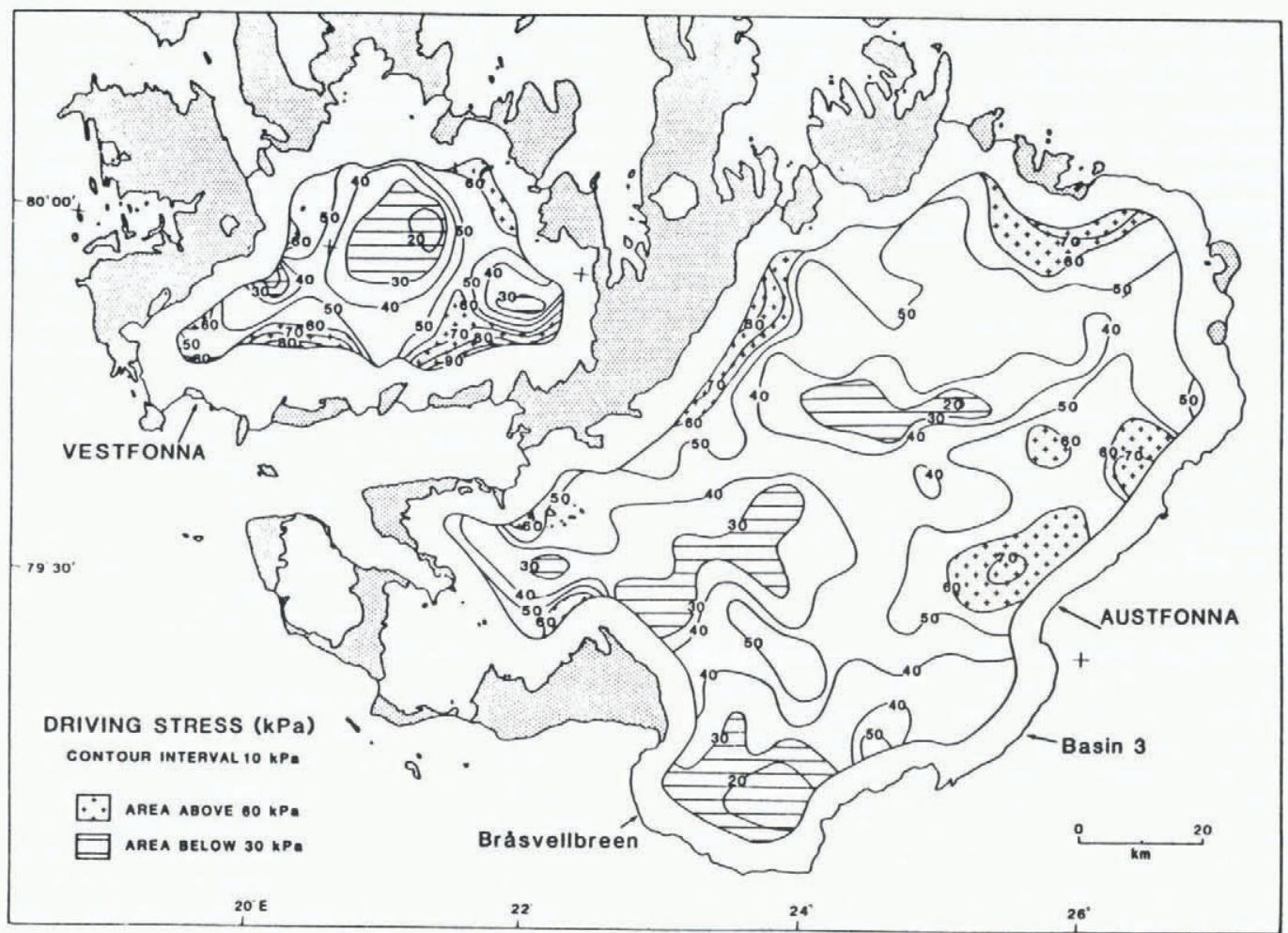

Fig. 6. The pattern of driving stresses on Nordaustlandet ice caps. Ice-surface slopes used to calculate driving stresses were averaged over $10 \mathrm{~km}$. No data are therefore available closer than $5 \mathrm{~km}$ to the ice margins.

in Figure 7. Variations in driving stress along flow lines in a number of basins fall into three broad groups, which are similar to those defined for ice-surface profiles. Four basins on Austfonna, which each have relatively low driving stresses over much of their length, are shown in Figure $7 \mathrm{a}$. They include Bråsvellbreen and Etonbreen, which are both known to have surged (Fig. 1). Driving stresses in basin 3 on Austfonna are very similar to those for the surging glaciers. In contrast, several drainage basins on Austfonna which have relatively high driving stresses $(100-180 \mathrm{kPa})$ near their margins are found in Figure $7 c$, together with profile of Vegafonna which has a similar distribution of stresses. The driving-stress profile of Leighbreen appears to be intermediate between these two groups (Fig. 7a). There is a marked similarity between the driving-stress profiles in Figure 7c and those from Antarctic outlet glaciers, where driving stresses reach a peak of between 120 and $240 \mathrm{kPa}$ about $50 \mathrm{~km}$ from the grounding line (Cooper and others, 1982).

Driving stresses in the four outlet glaciers on the south side of Vestfonna are also shown (Fig. 7b), but ice-thickness data were too sparse to calculate stresses along any other long profiles on this ice cap. Bodleybreen, which is surging at present, has the highest driving stresses of the four outlets (Fig. 7b). This value is also significantly higher than those found for Brásvellbreen and Etonbreen (Fig. 7a), which surged approximately 25-50 years ago, and may be associated with the glacier's continuing activity. Due to a lack of bedrock returns from radio-echo sounding, driving stresses are available from only restricted sections of Idunbreen but, where available, driving stresses in this outlet, Frazerbreen, and Aldousbreen do not generally rise to such high levels as those for basins in Figure 7c. Driving stresses are not calculated above 6.5 and $12.5 \mathrm{~km}$ up Aldousbreen and Frazerbreen, respectively, because of intersection of the flight lines with the shear zones above these points.

The effects on driving stress of relatively narrow channels which are present at the margins of some outlet glaciers can be assessed from the analysis of Nye (1965). Bodleybreen is the most topographically constrained outlet for which driving stress is calculated, with a width of approximately $2.5 \mathrm{~km}$ and centre-line depth of about $200 \mathrm{~m}$ near its terminus. These data yield a correction factor of 0.9 (Nye, 1965) by which calculated driving stress should be
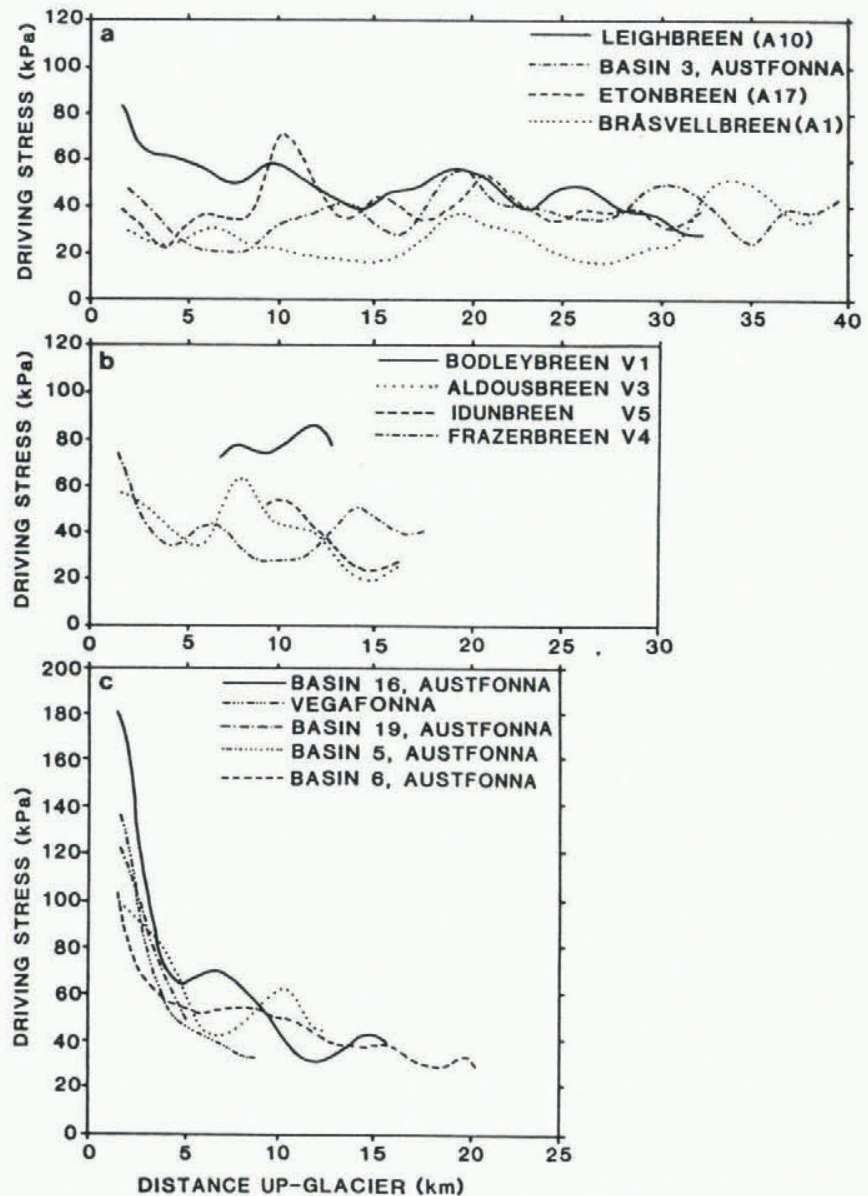

Fig. 7. Driving stresses along flow lines in 13 drainage basins on Nordaustlandet ice caps. Identification numbers locate the basins in Figure 1. Ice-surface slopes are averaged over $3 \mathrm{~km}$. (a) Drainage basins observed or interpreted to have surged. (b) The ice streams of southern Vestfonna. (c) Other drainage basins on Aust fonna and Vegafonna. 
multiplied to remove the effects of valley sides. Valley sides therefore inflate driving stress by a maximum of $10 \%$ in Nordaustlandet. On other Vestfonna outlet glaciers this factor usually accounts for less than $5 \%$ of total driving stress. Such corrections are neglected in this analysis due to their small magnitude.

The implications of variations in driving stress for understanding the dynamics of Nordaustlandet ice caps are discussed further in the next section.

\section{INTERPRETATION OF ICE DYNAMICS ON NORDAUST-}

\section{LANDET}

Discussion is divided into several sections, examining the dynamics of: (1) drainage basins which have been observed to surge; (2) the outlet glaciers of distinctive surface topography which drain the south side of Vestfonna; and (3) the remaining basins of Nordaustlandet ice caps for which data are available.

\section{Surging drainage basins}

Of the five largest drainage basins on Nordaustlandet which are known to have surged (Fig. 1), airborne altimetric and radio-echo sounding data are available along flow lines in four. Ice-cap long profiles of Bråsvellbreen, Etonbreen, and Søre Franklinbreen, which have all surged during the last half-century, fall below those predicted from theory, at least in their lower regions (Fig. 2). These observed profiles are interpreted as a result of rapid discharge of ice over a lubricated and probably deforming bed during the surge, followed by post-surge stagnation and thinning (Liestøl, 1969; Meier and Post, 1969). The latter process is particularly marked on Brásvellbreen, where mel lakes and complex supraglacial stream networks observed on Landsat imagery are not modified substantially from year to year by glacier flow. Similar melt features have been observed in basins or "scars" on the Barnes Ice Cap, Baffin Island, and were also interpreted to be a result of surges (Holdsworth, 1977). Driving stresses are also very low $(<40 \mathrm{kPa})$ on Brassvellbreen and in the lower $8 \mathrm{~km}$ of Etonbreen (Fig. 7a). The low driving stresses on Bråsvellbreen probably reflect the importance of in-situ ablation, low surface slopes, and low velocity rather than basal lubrication. The situation is less clear on Etonbreen, where some crevassing in its terminal regions indicates at least limited activity despite major retreat over the last decade (Dowdeswell, in press).

Bodleybreen, the other surging glacier for which glaciological data are available from airborne remote sensing, began to surge during the 1970 s (Dowdeswell, in press) and was still very crevassed and actively calving during airborne operations in 1983. This glacier has a surface profile only a little below that predicted by Equation (3) over its lower $8 \mathrm{~km}$, and is at a significantly greater elevation than the theoretical curve up-stream of this point (Fig. 3). Driving stresses are also in excess of $80 \mathrm{kPa}$ around this break in slope, and are considerably higher than those on Bråsvellbreen (Fig. 7). These characteristics may be indicative of its active state whereby its upper, accumulation area still contains a significant reservoir of ice which is sliding down-glacier over a lubricated bed. It is possible that the break in slope and peak in driving stress $10 \mathrm{~km}$ from the present terminus of Etonbreen may represent a stage in build-up towards renewed surge activity (Fig. 2).

The above discussion implies that glacier surges in Nordaustlandet result in low driving stresses and ice-surface profiles significantly lower than those predicted by theory. During the quiescent phase between surges, both driving stresses and the elevation of the ice surface increase, especially in the accumulation area. This is a pattern similar to that reported by Liestøl (1969) from Finsterwalderbreen in Spitsbergen, where observations were available at a number of intervals during a surge cycle. Holdsworth (1973, 1977) has also inferred that low ice-surface profiles in certain basins on the Barnes Ice Cap are a result of past surges. The profiles presented above provide particularly appropriate comparative data because the thermal regimes of the Barnes Ice Cap and Nordaustlandet ice caps are assumed to be similar (Schytt, 1969; Holdsworth, 1973).

Clarke and others (1984) have outlined a theory of surging in sub-polar glaciers which relies on the presence of an unlithified substrate. Such material deforms as ice thickness builds up between surges. The subglacial drainage system is eventually destroyed by increasing deformation, and a surge is triggered by increasing subglacial water pressure. About $57 \%$ of Bråsvellbreen and significant parts of Etonbreen and Søre Franklinbreen lie below present sealevel (Dowdeswell and others, 1986). They are therefore likely to be underlain by deformable sediments, implying that a surge mechanism similar to that of Clarke and others (1984) may be operating on these Svalbard sub-polar ice masses. More data on the nature of the ice-substrate interface in specific drainage basins are required, however, to test the applicability of this theory of glacier surging in Nordaustlandet. Unlike the case of certain Antarctic outlet glaciers, where McIntyre (1985) has inferred the presence of basal water from radio-echo strength measurement records (Neal, 1976), the calculation and interpretation of bedreflection coefficients is problematic on Nordaustlandet because of variations in absorption and scattering associated with ice close to its melting point (personal communication from J.L. Bamber).

\section{Ice streams on southern Vest fonna}

The three outlet glaciers of southern Vestfonna which have not been observed to surge provide examples of glacier long profiles (Fig. 3) which are similar to those present after surges (Fig. 2). Driving stresses are also lower near the margins of Aldousbreen and Frazerbreen (Fig. 7b) than for the basins shown in Figure 7c. These characteristics can however, be explained by mechanisms other than surging. These three outlet glaciers, along with Bodleybreen, have rough surface topography and crevassed surfaces which contrast markedly with the smooth and unbroken ice of the ridges between them (Fig. 4). These stream-like features, which are unlike those observed elsewhere on Nordaustlandet ice caps, may relate to periodic surges, as exemplified by Bodleybreen. By this explanation, however, it is not obvious why patterns of well-defined crevassing were present on Idunbreen, Frazerbreen, and Aldousbreen even when they were undergoing significant terminal retreat between 1970 and 1977 (Dowdeswell, in press). The implication is that, while they may also undergo periodic surges, these outlet glaciers normally flow faster than the surrounding ice which forms a series of ridges between them. They are therefore termed ice streams (Swithinbank, 1954).

Basal lubrication and/or deformation of an unlithified bed may be the processes leading to relatively fast flow in these outlet glaciers. Limited radio-echo returns from the bed in this area of Vestfonna suggest that the outlet glaciers may follow bedrock troughs. Such troughs are indicated on the long profiles of Frazerbreen and Aldousbreen as aircraft flight lines diverge from the axis of flow of these glaciers, and pass over their marginal shear zones on to the ridges between them, where ice is thinner (Fig. 3). However, it is not clear how pronounced these subglacial features are. A comparison between theoretical and observed surface profiles for Aldousbreen gives a further indication that basal sliding may influence the form and flow of these outlets. A second theoretical curve has been drawn with its origin at the shear zone marking the edge of Aldousbreen (Fig. 3), and above this point the theoretical and observed profiles coincide closely, suggesting that on the ridges between ice streams ice may be frozen to its bed. This interpretation is compatible with those of Schytt (1969) and Hollin (in Schytt, 1969), who first proposed that outlet glaciers might penetrate an outer ring of cold ice which Schytt suggested surrounded an inner zone at the pressure melting point.

Comparison with Antarctic data suggests that, in as much as they do not reach such high marginal driving stresses as the basins in Figure 7c, and noting that marginal stresses may be inflated by about $5 \%$ due to the presence of constraining rock walls (Nye, 1965), the outlets of southern Vestfonna have driving-stress profiles which are most similar to those of the Antarctic ice streams draining Byrd Land (Cooper and others, 1982). More data concerning both the surface velocity of these distinctive ice streams and the characteristics of their beds are, however, required before firmer conclusions can be reached regarding their 
dynamics. These features, which are a few kilometres wide and less than $25 \mathrm{~km}$ in length (Fig. 4), may have potential as small-scale analogues for larger features in the Antarctic and Greenland ice sheets.

\section{Other ice-cap drainage basins}

Most of the remaining drainage basins on Nordaustlandet for which data are available have long profiles similar to or above the steady-state profiles derived from Equation (3) (Fig. 5). Driving stresses are also relatively high $(>100 \mathrm{kPa})$ near the margins of these basins (Fig. 7c). Their dynamics are therefore assumed to differ from those basins discussed above. High driving stresses indicate that they may be frozen to their beds at least near the ice margin. This suggestion is compatible with Schytt's (1969) interpretation of the thermal regime of Nordaustlandet ice caps and the observed distribution of $10 \mathrm{~m}$ ice temperatures (Dowdeswell, unpublished), although it gives little detail on the up-glacier extent of this zone of freezing. Suspended sediment plumes observed offshore of basins 5 and 6 on Austfonna from Landsat imagery imply that basal melting may extend relatively close to the ice margins (Dowdeswell, unpublished). Mathematical modelling of ice temperatures will help to resolve this problem, but it first requires the collection of additional field observations on mass balance and ice temperatures.

Basin 3 on Austfonna and, to a less-marked degree, Leighbreen are exceptions to the general pattern of profiles and stresses in Figures 5 and $7 \mathrm{c}$. The low observed surface profiles and driving stresses indicate that either post-surge stagnation or basal sliding may be taking place. Two lines of evidence support the interpretation of basin 3 as a surging glacier in the quiescent phase. First, Solheim and Pfirman (1985) have described a distinctive sea-floor morphology outside the present terminus of Brassvellbreen which they suggest is closely related to its surge between 1936 and 1938. Solheim (personal communication) has reported that similar sea-floor features are found beyond the present margins of basin 3. Secondly, Ahlmann (1933) has studied the records of Nordenskiöld's traverse of Nordaustlandet ice caps in 1873, and showed that the reports of very heavily crevassed ice in the interior of Austfonna are from the areas we define as basin 3 . Crevasses have not been observed on this part of Austfonna by subsequent traverse parties. Liestøl (personal communication) has proposed that this crevassing may therefore represent a surge of the basin during the 1870s.

The notion that the presence of a deformable substrate might influence driving stresses and ice-surface profiles in parts of Nordaustlandet is appealing because over $28 \%$ of Austfonna, mainly on its east side, lies below present sealevel (Dowdeswell and others, 1986). Boulton and others (1982) have reported the deposition of marine muds at a number of points around the coast of Svalbard in association with isostatic submergence after ice retreated from its maximum extent about 10000 years ago. Elverhøi and Solheim (1983) have mapped similar sediments in the western Barents Sea, and marine cores in unlithified sediments have also been collected immediately offshore of the east coast of Nordaustlandet (personal communication from A. Elverhøi). It is likely, therefore, that such unlithified material underlies at least the proportion of those basins that are below contemporary sea-level.

The lowest $10 \mathrm{~km}$ of basins 5 and 6 (Fig. 1) provide examples of basins with beds in part below sea-level, and yet both have significantly different surface profiles and marginal driving-stress values from basin 3 and Leighbreen. This indicates that relatively rapid movement associated with a deformable bed, unless it occurs during periodic glacier surging, is unlikely to be a major cause of the observed pattern of surface profiles and driving stresses in these two anomalous drainage basins. Instead, it is suggested that basin 3 and Leighbreen may have surged relatively recently, the higher surface profile and driving stresses for Leighbreen indicating that it might be the closer of the two basins to a further surge. Such rapid advances have not been observed in the past, but continued monitoring of Landsat satellite imagery will enable any future surge activity on Nordaustlandet ice caps to be identified.

\section{CONCLUSIONS}

The drainage basins comprising Nordaustlandet ice caps may be subdivided into three groups on the basis of their observed surface profiles, driving stresses, and other surface characteristics observed using remote-sensing methods.

(1) Basins with low driving stresses and surface profiles, some of them clearly stagnant, are associated with the quiescent phase between glacier surges, and are in various stages of build-up to renewed surge activity. As well as basins known to surge, basin 3 and Leighbreen on Austfonna are likely to fall into this category.

(2) The ice streams draining southern Vestfonna have low surface profiles and relatively low driving stresses. They are, however, interpreted to be flowing continuously at a relatively faster rate than the ice ridges between them, due to the presence of marked shear zones at their margins. Basal melting, perhaps combined with substrate deformation, is proposed to be responsible for the regime of these glaciers. They may also surge, as in the case of Bodleybreen, indicating that the term "fast" flow is a relative one related to the velocity of ice comprising the surrounding ridges.

(3) The remaining basins studied on Austfonna, Vestfonna, and Vegafonna fall into a third class, with high marginal driving stresses and high surface profiles. They are interpreted to be frozen to their beds at least near the margins, while relatively high $10 \mathrm{~m}$ temperatures near the centre of the ice caps suggest that basal melting occurs there (Schytt, 1969; Dowdeswell, unpublished). Some of these basins may also surge, particularly those where a part of the basin is below sea-level, and therefore probably underlain by considerable thicknesses of deformable sediments. However, none of the basins in this group has been observed to surge, and few have the break in surface profile separating an upper, accumulation area from a lower, stagnant zone which is found to be characteristic of some sub-polar glaciers as they approach the active phase of the surge cycle (Liestøl, 1969; Clarke and others, 1984). Continued monitoring of Nordaustlandet ice caps using satellite imagery will allow the identification of future surges of basins in this part of Svalbard.

Two concluding points should be made. First, more field data on mass balance, ice temperatures, and velocities, and more information from the continuing analysis of bottom radio-echo returns, combined with mathematical modelling studies, are required to test the above interpretations of drainage-basin dynamics. Secondly, three dynamic classes of basin have been identified on Nordaustlandet. This implies that Nordaustlandet ice caps may be a very useful area for further research, providing a wide variety of dynamic regimes at a scale that is significantly more tractable logistically than that of the large ice sheets.

\section{ACKNOWLEDGEMENTS}

This study was funded through a U.K. Natural Environment Research Council (NERC) studentship to the author and NERC grant GR3/4463 to Dr D.J. Drewry. The cooperation of the Norsk Polarinstitutt in a joint field programme during 1983 is gratefully acknowledged, and collaborative meetings were supported by a NATO grant. Drs D.J. Drewry and N.F. McIntyre kindly commented on drafts of this paper.

\section{REFERENCES}

Ahlmann, H.W:son. 1933. Scientific results of the Swedish-Norwegian Arctic expedition in the summer of 1931. Part III. The inland cartography of North-East Land. Geografiska Annaler, Árg. 15, Ht. 1, p. 47-68. 
Binney, F.G. [1925]. With seaplane and sledge in the Arctic. London, Hutchinson.

Boulton, G.S., and Jones, A.S. 1979. Stability of temperate ice caps and ice sheets resting on beds of deformable sediment. Journal of Glaciology, Vol. 24, No. 90, p. 29-43.

Boulton, G.S., and others. 1982. A glacio-isostatic facies model and amino acid stratigraphy for late Quaternary events in Spitsbergen and the Arctic, by G.S. Boulton [and 13 others]. Nature, Vol. 298, No. 5813, p. 437-41.

Budd, W.F., and Jenssen, D. 1975. Numerical modelling of glacier systems. [Union Géodésique et Géophysique Internationale. Association Internationale des Sciences Hydrologiques. Commission des Neiges et Glaces.] Symposium. Neiges et glaces. Actes du colloque de Moscow, août 1971, p. 257-91. (IAHS-AISH Publication No. 104.)

Clarke, G.K.C., and others. 1984. Flow, thermal structure, and subglacial conditions of a surge-type glacier, by G.K.C. Clarke, S.G. Collins, and D.E. Thompson. Canadian Journal of Earth Sciences, Vol. 21, No. 2, p. 232-40.

Cooper, A.P.R., and others. 1982. Driving stresses in the Antarctic ice sheet, by A.P.R. Cooper, N.F. McIntyre, and G. de Q. Robin. Annals of Glaciology. Vol. 3, p. 59-64.

Dowdeswell, J.A. In press. Remote sensing of ice cap outlet glacier fluctuations on Nordaustlandet, Svalbard. Polar Research.

Dowdeswell, J.A. Unpublished. Remote sensing studies of Svalbard glaciers. [Ph.D. thesis, University of Cambridge, 1984.]

Dowdeswell, J.A., and Drewry, D.J. 1985. Place names on the Nordaustlandet ice caps, Svalbard. Polar Record, Vol. 22 , No. 140 , p. 519-23.

Dowdeswell, J.A., and others. 1986. Digital mapping of the Nordaustlandet ice caps from airborne geophysical investigations, by J.A. Dowdeswell, D.J. Drewry, A.P.R. Cooper, M.R. Gorman, O. Liestøl, and O. Orheim. Annals of Glaciology, Vol. 8, p. 51-58.

Drewry, D.J. 1983[a]. Antarctic ice sheet: aspects of current configuration and flow. (In Gardner, R., and Scoging, S., ed. Megageomorphology. Oxford, Clarendon Press, p. 18-38.)

Drewry, D.J. 1983[b]. The surface of the Antarctic ice sheet. (In Drewry, D.J., ed. Antarctica: glaciological and geophysical folio. Cambridge, University of Cambridge. Scott Polar Research Institute, Sheet 2.)
Drewry, D.J., and Liestøl, O. 1985. Glaciological investigations of surging ice caps in Nordaustlandet, Svalbard, 1983. Polar Record, Vol. 22, No. 139, p. 359-78.

Drewry, D.J., and Robin, G. de Q. 1983. Form and flow of the Antarctic ice sheet during the last million years. (In Robin, G. de Q., ed. The climatic record in polar ice sheets. Cambridge, etc., Cambridge University Press, p. 28-38.)

Elverhøi, A., and Solheim, A. 1983. Physical environment, western Barents Sea, 1:1500 000. Sheet A. Surface sediment distribution. Norsk Polarinstitutt. Skrifter, Nr. 179A.

Holdsworth, G. 1973. Evidence of a surge on Barnes Ice Cap, Baffin Island. Canadian Journal of Earth Sciences, Vol. 10, No. 10, p. 1565-74.

Holdsworth, G. 1977. Surge activity on the Barnes Ice Cap. Nature, Vol. 269, No. 5629, p. 588-90.

Liestøl, O. 1969. Glacier surges in west Spitsbergen Canadian Journal of Earth Sciences, Vol. 6, No. 4, Pt. 2, p. 895-97.

McIntyre, N.F. 1985. The dynamics of ice-sheet outlets Journal of Glaciology, Vol. 31, No. 108, p. 99-107.

Meier, M.F., and Post, A. 1969. What are glacier surges? Canadian Journal of Earth Sciences, Vol. 6, No. 4, Pt. 2, p. $807-17$

Neal, C.S. 1976. Radio-echo power profiling. Journal of Glaciology, Vol. 17, No. 77, p. 527-30.

Nye, J.F. 1965. The flow of a glacier in a channel of rectangular, elliptic or parabolic cross-section. Journal of Glaciology, Vol. 5, No. 41, p. 661-90.

Paterson, W.S.B. 1981. The physics of glaciers. Second edition. Oxford, etc., Pergamon Press. (Pergamon International Library.)

Paterson, W.S.B. 1983. Surface profiles of ice sheets. (In Robin, G. de Q., ed. The climatic record in polar ice sheets. Cambridge, etc., Cambridge University Press, p. 22-25.)

Sandford, K.S. 1929. The glacial conditions and Quaternary history of North-East Land. Geographical Journal, Vol. 74 , No. 5 , p. $451-70$; No. 6 , p. 543-52.

Schytt, V. 1969. Some comments on glacier surges in eastern Svalbard. Canadian Journal of Earth Sciences, Vol. 6, No. 4, Pt. 2, p. $867-73$.

Solheim, A., and Pfirman, S.L. 1985. Sea-floor morphology outside a grounded, surging glacier; Bråsvellbreen, Svalbard. Marine Geology, Vol. 65, p. 127-43.

Swithinbank, C.W.M. 1954. "Ice streams". Polar Record, Vol. 7 , No. 48 , p. $185-86$ 